\title{
DVD Regimen
}

National Cancer Institute

\section{Source}

National Cancer Institute. DVD Regimen. NCI Thesaurus. Code C63500.

A regimen consisting of liposomal doxorubicin, vincristine and dexamethasone used as induction therapy for plasma cell myeloma. 